\title{
Effect of Glucagon Like Peptide 1| (GLP1) Analogues on Obese Egyptians With and Without Diabetes
}

\author{
KHALED A. ELBANA, M.D. \\ The Department of Internal Medicine, Faculty of Medicine, Zagazig University, Zagazig, Egypt
}

\begin{abstract}
Background: The Glucagon Like Peptide 1 (GLP1) receptor agonists are a new class for treatment of both type 2 diabetes and obesity.

Aim of Study: To evaluate efficacy of GLP1 analogues in both weight reduction and glycemic control in obese Egyptians with and without diabetes.

Patients and Methods: This intervention study was conducted from August 2017 to August 2018. Total of 40 patients were divided into 3 groups: Obese group, obese group with diabetes \& obese group with diabetes after failure to lose $10 \%$ of their initial weight after bariatric surgery. Clinical data were collected, anthropometric measures and laboratory investigation included fasting blood glucose and $\mathrm{HbA}_{1 \mathrm{c}}$ in the beginning and every 3 months for a year were done.

Results: This study showed statistically significant body weight and BMI reduction in all groups, there was statistically significant reduction of fasting blood glucose, and $\mathrm{HBA}_{1 \mathrm{c}}$ in the 2 nd $\& 3^{\text {rd }}$ group.

Conclusion: GLP1 analogues are effective in treatment of obese patients with and without diabetes.
\end{abstract}

Key Words: GLP1 analogues-Type 2 diabetes - Obesity.

\section{Introduction}

MOST patients with type 2 diabetes are obese (diabesity) and this can explain the dramatic increase in the prevalence of type 2 diabetes last years. Insulin resistance may be the main link [1]

The Glucagon Like Peptide 1 (GLP1) receptor agonists are a new class of injectable drugs with double benefit as it can be used for treat both type 2 diabetes and obesity [2]

For this reasons, the aim of this research to evaluate the effect of GLP1 analogues on obese Egyptian patients with and without diabetes.

Correspondence to: Dr. Khaled A. Elbana, E-Mail: aboamro76@yahoo.com

\section{Patients and Methods}

This intervention non-randomized controlled study had been conducted in Internal Medicine Outpatient Clinic at Zagazig University Hospitals from August 2017 to August 2018. We started the study on 40 subjects; after exclusion of patients with diabetes mellitus type 1 or patients with family history of medullary thyroid carcinoma and patients suffering from gastroparesies. Their ages ranged from 30 to 65 years; with mean \pm SD $48.6 \pm 9.6$ years.

The patients divided into three groups:

- Group I: Obese group included 14 patients.

- Group II: Obese group with diabetes included 13 patients.

- Group III: Obese group with diabetes, after failure to lose $10 \%$ of their initial weight, 6 month after bariatric surgery included 13 patients.

Patients were subjected to thorough history taking and anthropometric measures were calculated including weight, BMI. Full clinical examination and routine investigations were done. Specific investigations included $\mathrm{HbA}_{1 \mathrm{c}}$, fasting blood glucose ethical.

Written informed consent was taken from the patient to participate in the study. Approval for performing the study was obtained from Internal Medicine and Medical Biochemistry Departments, Zagazig University Hospitals after taking Institutional Review Board (IRB) approval.

\section{Statistical analysis:}

Data analysis was performed using the software SPSS (Statistical Package for the Social Sciences) Version 20. Quantitative variables were described using their means and standard deviations. Cate- 
gorical variables were described using their absolute frequencies. Kolmo gorov-Smirnov (distributiontype) and Levene (homogeneity of variances) tests were used to verify assumptions for use in parametric tests. To compare means, independent sample t test was used when appropriate. Nonparametric test (Mann Whitney) was used to compare means when data was not normally distributed and to compare medians in categorical data. To assess the best cutoff for study variables, ROC curve analysis was used. The level statistical significance was set at $5 \%(p<0.05)$.highly significant difference was present if $p \leq 0.001$.

\section{Results}

This study included 40 patients divided into 3 groups, the 1 st group was obese non diabetic consisted of 14 patients, 2 nd group was obese diabetic and consisted of 13 patients and the 3 rd group was obese diabetic who failed to lose $10 \%$ of their initial weight within 6 months after bariatric surgery and also consisted of 13 patients. In the three groups all variables were measured 4 times. 1 st before using GLP-1 receptor agonist; subcutaneous injection of $3 \mathrm{mg}$ liraglutide and then every 3 months later for one year follow-up.

Table (1): Comparing serial BMI measures between the studied groups.

\begin{tabular}{|c|c|c|c|c|c|}
\hline Variable & $\begin{array}{c}\text { Group 1 } \\
(\mathrm{N}=14) \\
\text { Obese } \\
\text { patients }\end{array}$ & $\begin{array}{c}\text { Group } 2 \\
(\mathrm{~N}=13) \\
\text { Obese } \\
\text { with } \\
\text { diabetes }\end{array}$ & $\begin{array}{c}\text { Group } 3 \\
(\mathrm{~N}=13) \\
\text { Obese with } \\
\text { diabetes } \\
\text { after } \\
\text { bariatric } \\
\text { surgery }\end{array}$ & $\begin{array}{l}\text { F- } \\
\text { test }\end{array}$ & $\begin{array}{c}p^{-} \\
\text {value! }\end{array}$ \\
\hline \multicolumn{6}{|l|}{ Baseline BMI: } \\
\hline $\begin{array}{l}\text { Mean } \pm \text { SD } \\
\text { Range }\end{array}$ & $\begin{array}{l}43.1 \pm 8.4 \\
(28.8-53.6)\end{array}$ & $\begin{array}{l}37.2 \pm 4.9 \\
(31.4-49.2)\end{array}$ & $\begin{array}{l}41.9 \pm 6.5 \\
(34.2-54.8)\end{array}$ & 1.6 & 0.2 \\
\hline \multicolumn{6}{|l|}{ BMI after 3 months: } \\
\hline $\begin{array}{l}\text { Mean } \pm S D \\
\text { Range }\end{array}$ & $\begin{array}{l}42.1 \pm 8.3 \\
(28.8-53.6)\end{array}$ & $\begin{array}{l}36.6 \pm 4.4 \\
(30.9-47.8)\end{array}$ & $\begin{array}{l}41.1 \pm 6.3 \\
(33.5-53.8)\end{array}$ & 1.7 & 0.18 \\
\hline \multicolumn{6}{|l|}{ BMI after 6 months: } \\
\hline $\begin{array}{l}\text { Mean } \pm \mathrm{SD} \\
\text { Range }\end{array}$ & $\begin{array}{l}40.9 \pm 8.1 \\
(28-51.2)\end{array}$ & $\begin{array}{l}36.2 \pm 4.7 \\
(29.7-46.2)\end{array}$ & $\begin{array}{l}39.8 \pm 6.2 \\
(32.2-52.1)\end{array}$ & 1.9 & 0.15 \\
\hline \multicolumn{6}{|l|}{ BMI after 9 months: } \\
\hline $\begin{array}{l}\text { Mean } \pm \text { SD } \\
\text { Range }\end{array}$ & $\begin{array}{l}37.8 \pm 7.8 \\
(26.9-48.7)\end{array}$ & $\begin{array}{l}35.1 \pm 4.4 \\
(29.3-45)\end{array}$ & $\begin{array}{l}38.6 \pm 6.3 \\
(30.8-50.2)\end{array}$ & 1.9 & 0.15 \\
\hline \multicolumn{6}{|l|}{ BMI after 12 months: } \\
\hline $\begin{array}{l}\text { Mean } \pm \text { SD } \\
\text { Range }\end{array}$ & $\begin{array}{l}33.8 \pm 2.8 \\
(22.9-35.5)\end{array}$ & $\begin{array}{l}31.2 \pm 4.1 \\
(28.3-35)\end{array}$ & $\begin{array}{l}33.5 \pm 2.3 \\
(30.8-42)\end{array}$ & 1.9 & 0.15 \\
\hline $\begin{array}{l}\text { - ANOVA test for } \\
\text { repeated measures }\end{array}$ & 2.1 & 23 & 0.4 & & \\
\hline$\cdot p$-value ${ }^{\wedge}$ & $0.04 *$ & $0.001 * *$ & $0.001 * *$ & & \\
\hline
\end{tabular}

This table shows that there was statistically significant difference (reduction) in BMI between the four times in the three studied groups. But, there was no statistically significant difference between the studied groups in BMI in the four times.

Table (2): Comparing serial fasting blood glucose measures between the studied groups.

\begin{tabular}{|c|c|c|c|c|c|}
\hline Variable & $\begin{array}{c}\text { Group } 1 \\
(14) \\
\text { Obese } \\
\text { non } \\
\text { diabetic }\end{array}$ & $\begin{array}{c}\text { Group } 2 \\
(13) \\
\text { Obese } \\
\text { diabetes }\end{array}$ & $\begin{array}{c}\text { Group } 3 \\
(13) \\
\text { Obese } \\
\text { diabetes } \\
\text { after } \\
\text { bariatric } \\
\text { surgery }\end{array}$ & $\begin{array}{l}\text { F- } \\
\text { test }\end{array}$ & $\begin{array}{c}p^{-} \\
\text {value! }\end{array}$ \\
\hline - Baseline & $\begin{array}{l}93.5 \pm 19.9 \\
(76-154)\end{array}$ & $\begin{array}{l}251.5 \pm 49.9 \\
(174-310)\end{array}$ & $\begin{array}{l}235 \pm 66.8 \\
(98-370)\end{array}$ & 20.9 & $0.001 * *$ \\
\hline - FBG 1st time & $\begin{array}{l}85.2 \pm 9.8 \\
(76-115)\end{array}$ & $\begin{array}{l}147.6 \pm 35.9 \\
(98-240)\end{array}$ & $\begin{array}{l}137.2 \pm 29.2 \\
(76-190)\end{array}$ & 42.9 & $0.001 * *$ \\
\hline $\begin{array}{c}\text { - FBG 2nd time } \\
\text { mean } \pm \text { SD }\end{array}$ & $\begin{array}{l}85.2 \pm 6.2 \\
(77-94)\end{array}$ & $\begin{array}{l}119.1 \pm 26.2 \\
(86-190)\end{array}$ & $\begin{array}{l}124 \pm 16.6 \\
(78-140)\end{array}$ & 20.8 & $0.001 * *$ \\
\hline - FBG 3rd time & $\begin{array}{l}88.2 \pm 14.2 \\
(70-129)\end{array}$ & $\begin{array}{l}122.5 \pm 25.3 \\
(90-201)\end{array}$ & $\begin{array}{l}117.5 \pm 15.3 \\
(74-135)\end{array}$ & 13.9 & $0.001 * *$ \\
\hline - FBG 4th time & $\begin{array}{l}86.2 \pm 11.3 \\
(70-121)\end{array}$ & $\begin{array}{l}118.5 \pm 20.1 \\
(90-180)\end{array}$ & $\begin{array}{l}100.5 \pm 10.2 \\
(72-120)\end{array}$ & 11.2 & $0.001 * *$ \\
\hline $\begin{array}{l}\text { - ANOVA test } \\
\text { for repeated } \\
\text { measures }\end{array}$ & 1.1 & 39 & 31 & & \\
\hline - $p$-value ${ }^{\wedge}$ & 0.3 & $0.001 * *$ & $0.001 * *$ & & \\
\hline
\end{tabular}

$* *$ : Statistically highly significant difference $(p \leq 0.001)$.

This table shows that there was highly statistically significant difference between the three studied groups in FBG in the four times. Also, there was statistically significant difference in FBG between the four times in each of the three studied groups.

Table (3): Comparing serial $\mathrm{HBA}_{1 \mathrm{c}}$ measures between the studied groups.

\begin{tabular}{|c|c|c|c|c|c|}
\hline Variable & $\begin{array}{c}\text { Group } 1 \\
(14) \\
\text { Obese } \\
\text { non } \\
\text { diabetic } \\
\text { Mean } \pm \text { SD } \\
\text { Range }\end{array}$ & $\begin{array}{c}\text { Group } 2 \\
(13) \\
\text { Obese } \\
\text { diabetes } \\
\text { Mean } \pm \text { SD } \\
\text { Range }\end{array}$ & $\begin{array}{c}\text { Group } 3(13) \\
\text { Obese } \\
\text { diabetes after } \\
\text { bariatric } \\
\text { surgery } \\
\text { Mean } \pm \text { SD } \\
\text { Range }\end{array}$ & $\begin{array}{l}\text { F- } \\
\text { test }\end{array}$ & $\begin{array}{c}p^{-} \\
\text {value! }\end{array}$ \\
\hline - Baseline & $\begin{array}{l}5.1 \pm 0.6 \\
(4.2-6.3)\end{array}$ & $\begin{array}{l}10.1 \pm 1.2 \\
(8.1-12)\end{array}$ & $\begin{array}{l}8.8 \pm 1.7 \\
(4.9-12)\end{array}$ & 10.7 & 0.001 ** \\
\hline $\begin{array}{l}\cdot \mathrm{HBA1c} 1 \mathrm{st} \\
\text { time }\end{array}$ & $\begin{array}{l}4.8 \pm 0.4 \\
(4.2-5.9)\end{array}$ & $\begin{array}{l}7.9 \pm 0.5 \\
(7-9)\end{array}$ & $\begin{array}{l}7.5 \pm 0.8 \\
(5.2-8.3)\end{array}$ & 59.7 & $0.001 * *$ \\
\hline $\begin{array}{l}\text { - HBA1c 2nd } \\
\text { time }\end{array}$ & $\begin{array}{l}4.9 \pm 0.4 \\
(4.5-6.2)\end{array}$ & $\begin{array}{l}7.4 \pm 0.3 \\
(7-8.2)\end{array}$ & $\begin{array}{l}7.2 \pm 0.6 \\
(5-7.8)\end{array}$ & 101.5 & 0.001 ** \\
\hline $\begin{array}{l}\text { - HBA1c 3rd } \\
\text { time }\end{array}$ & $\begin{array}{l}5.1 \pm 0.5 \\
(4.5-6.5)\end{array}$ & $\begin{array}{l}7.3 \pm 0.2 \\
(7-8.3)\end{array}$ & $\begin{array}{l}7.2 \pm 0.5 \\
(5.2-7.8)\end{array}$ & 97.1 & $0.001 * *$ \\
\hline $\begin{array}{l}\cdot \text { HBA1c 4th } \\
\text { time }\end{array}$ & $\begin{array}{l}4.9 \pm 0.3 \\
(4.5-6.2)\end{array}$ & $\begin{array}{l}6.6 \pm 0.5 \\
(5.8-6.9)\end{array}$ & $\begin{array}{l}6.7 \pm 0.6 \\
(5.2-7.5)\end{array}$ & 95.1 & 0.001 ** \\
\hline $\begin{array}{l}\text { - ANOVA test } \\
\text { for repeated } \\
\text { measures }\end{array}$ & 0.5 & 36 & 7.6 & & \\
\hline - $p$-value ${ }^{\wedge}$ & 0.6 & $0.001 * *$ & $0.001 * *$ & & \\
\hline
\end{tabular}

**: Statistically highly significant difference $(p \leq 0.001)$. 
This table shows that there was highly statistically significant difference between the studied groups in $\mathrm{HBA}_{1 \mathrm{c}}$ in the four times. Also, there was statistically significant difference in $\mathrm{HBA}_{1 \mathrm{c}}$ between the four times in the 2 nd and 3 rd studied groups but not statistically significant in the 1 st group.

\section{Discussion}

Obesity is one of the most important public health issue worldwide [3] .

The Glucagon Like Peptide 1 (GLP1) receptor agonists are a new class of injected drugs for the treatment of both type 2 diabetes and obesity, they are associated with considerable $\mathrm{HBA}_{1 \mathrm{C}}$ reduction and weight loss with a low risk of hypoglycemia [2].

Therefore, the present study was designed to estimate the role of GLP1 analogues in obese patients with and without diabetes including patients who failed to lose weight after bariatric surgery.

We found statistically significant reduction in weight, BMI in all studied groups in every 3 months evaluation for one year. But, there was no statistically significant difference between the studied groups in BMI in the four times, which means reflect the efficacy of GLP1 analogues in obese patient either with diabetes or without even after failure to lose weight after bariatric surgery.

This in in agreement with previous study showed that weight loss with liraglutide which is dose dependent to $3.0 \mathrm{mg}$ once daily in obese subjects without diabetes in comparison to placebo or orlistat [4].

Also in agreement with our results, study evaluated the efficacy of liraglutide in patients with prior bariatric surgery who experienced either suboptimal weight loss or weight regain after their procedures with recommended dose $0.6 \mathrm{mg} \mathrm{SC}$ once daily increasing to maximal dose of $3 \mathrm{mg} / \mathrm{day}$ and after 3 months of follow-up, mean weight and BMI reduction were $8.38 \pm 9.19 \mathrm{Kg}$ and $2.94 \pm 3.14$ $\mathrm{Kg} / \mathrm{m}$ respectively [5]

Similarly significant body weight reductions in patients randomized to $3 \mathrm{mg}$ liraglutide when compared with placebo at 56 weeks alongside increased 5\% and $10 \%$ responder rates [6].

Interestingly, supraphysiological doses of GLP1 reduce appetite and food intake in both lean and obese subjects, physiological GLP-1 doses reduces appetite and food intake in only lean subjects [7] GLP-1 has been found to delay gastric emptying in healthy lean, obese and T2DM subjects [8].

In the present study; there was statistically significant reduction in FBG and $\mathrm{HBA}_{1 \mathrm{c}}$ in patient with diabetes ( 2 nd and 3 rd groups). This may be explained by body weight reduction in agreement with recent clinical trial showed that about $50 \%$ of patients with T2DM achieved remission to nondiabetic state after weight loss and this may be associated with the early and sustained improvement of beta cells function [9].

In obese patients with T2DM even modest weight loss have been shown to improve glycemic control and patients who lose weight achieve target $\mathrm{HbA}_{1 \mathrm{c}}$ more likely those with stable weight [10].

We can conclude that GLP1 receptor agonists are effective tool in both glycemic control and weight reduction even in patients who failed to lose weight after bariatric surgery.

\section{Acknowledgements:}

We thank all the individuals share in this study.

\section{Conflicts of interest:}

The authors declare that they have no competing interests.

\section{References}

1- ARONNE L.J. and ISOLDI K.K.: Overweight and obesity: Key components of cardiometabolic risk. Clin. Cornerstone, 8: 29-37, 2007.

2- American Diabetes Association. Obesity Management for the Treatment of Type 2 Diabetes, Diabetes Care, Jan., 42 (Supplement 1): S81-S89, 2019.

3- BUCHWALD H., AVIDOR Y., BRAUNWALD E., et al.: Bariatric Surgery A Systematic Review and Meta-analysis. JAMA, 292: 1724-37, 2004.

4- WADDEN T.A., HOLLANDER P., KLEIN S., et al.: Weight maintenance and additional weight loss with liraglutide after low-calorie-diet-induced weight loss: The SCALE Maintenance randomized study. Int. J. Obes. (Lond), 3 7: 1443 -51, 2013.

5- NAIM SHEHADEH, WISAM A.Z., NEHAMA Z.L., et al.: Liraglutide treatment in post-bariatric surgery patients who failed to maintain weight reduction. Surgery for Obesity and Related Diseases, October, Volume 13, Issue 10, Supplement, Page S144, 2017.

6- DAVIES M.J., BERGENSTAL R., BODE B., et al.: Efficacy of Liraglutide for Weight Loss Among Patients With Type 2 Diabetes: The SCALE Diabetes Randomized Clinical Trial. JAMA, 314: 687-99, 2015. 
7- CEGLA J., TROKE R.C., JONES B., et al.: Coinfusion of low-dose GLP-1 and glucagon in man results in a reduction in food intake. Diabetes, 63: 3711-20, 2014.

8- CLEGG M.E., RANAWANA V., SHAFAT A., et al.: Soups increase satiety through delayed gastric emptying yet increased glycaemic response. Eur. J. Clin. Nutr., 67: 8-11, 2013.

9- ROY TAYLOR, AHMED A.M. and SVIATLANA Z.:
Remission of human type 2 diabetes requires decrease in liver and pancreas fat content but is dependent upon capacity for b cell recovery. Cell Metabolism: Clinical and Translation Report, 28: 547-56, 2018.

10- FELDSTEIN A.C., NICHOLS G.A., SMITH D.H., et al.: Weight change and glycemic control after diagnosis of type 2 diabetes. J. Gen. Intern. Med., 23 (9): 1339-45, 2008.

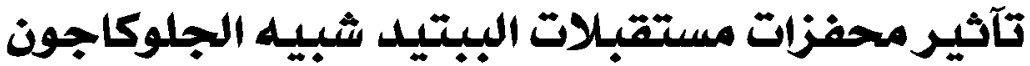

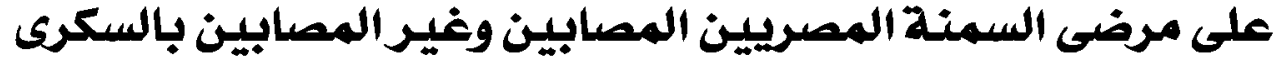

السمنة هى حالة طبية تتراكم فيها الدهون الزائدة فى الجسم إلى آملدى الذى قد يكن له تاتثير سلبى على الصحة، وعادة ما يعتبر الناس

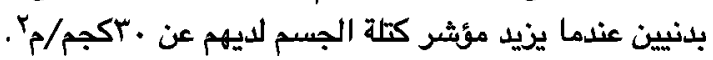

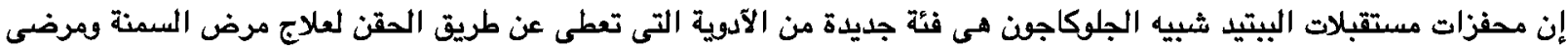

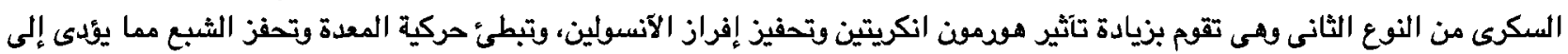

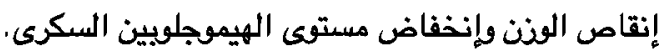

الهدف من الدراسة: هو دراسة تآثير محفزات مستقبلات اليتيد ثبيه الجلوكاجون على مرضى السمنة المصريين المصابين وغير المصابين

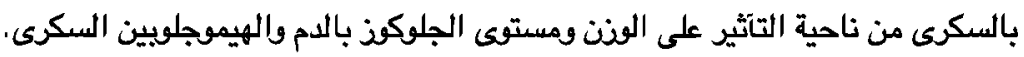

طرق وآدوات الدراسة: آجريت هذه الدراسة ف العيادة الخارجية لقسم الباطنة العامة جامعة الزقازيق فى الفترة من آغسطس VIV ب إلى

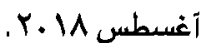

آشترك فى الدراسة -ع سخخص تم تقسيهم كالآثى: 1- 1 ا شخص يعانون من السمنة. r- rا شخص يعانون من السمنة والسكرى. r- rا شخص يعانون من السمنة والسكرى بعد فشل إنقاص ــ بـ من وذنهم بعد 7 شهود من إجراء جراحة لعلاج السمنة. تم آخذ التاريخ المرضى والفحص السريرى الشامل المرضى فى المجموعات الثلاث. تم عمل متابعة كل ثلاثة آشهر لجميع المرضى لمتابعة الوذن ومستوى الجلوكوذ الصائم بالدم والهيموجلوبين السكرى. النتائج: تعمل آدوية محفزات مستقبلات اليتيد شبيه الجوكاجون بشكل فعال فى إنقاص الونن في مرضى السمنة وتخفيض مستوى الجلوكوذ بالدم وتقليل مستوى الهيموجلوبين السكرى فى مرضى السكرى من النوع الثانى. التوصيات: يوصى بإستخدام محفزات مستقبلات البيتيد شبيه الجوكاجون فى مرضى السمنة كما يوصى بإستخدام هذه الآدوية فى مرضى السكرى من النوع الثانى المصابين بالسمنة. 